\title{
CONFLICTS BETWEEN ENGINEERS AND TECHNICIANS: THE CASE OF SRI LANKAN HOTEL FACILITIES' MAINTENANCE DEPARTMENTS
}

\author{
INDIKATIYA I.H.P.R. ${ }^{1}$, ARAMBEKUMBURA A.K.G.I.D. ${ }^{2}$ \& HADIWATTAGE C. 3 \\ ${ }^{1}$ Faculty of Graduate Studies, University of Kelaniya, Kelaniya, Sri Lanka \\ 2,3 Department of Building Economics, University of Moratuwa, Moratuwa, Sri Lanka \\ 1pabasararavindu94@gmail.com, 2arambekumburaid@gmail.com,3chandanieqs@yahoo.com
}

\begin{abstract}
Conflicts between engineers and technicians in maintenance departments of hotels can be impacted on both individual and organizational performance either constructively or destructively. Generally, the destructive impacts of conflicts on organizational performance are severe than constructive impacts. Therefore, understanding the nature of the major conflicts between engineers and technicians in maintenance departments is significant to provide high- quality maintenance services within hotel facilities to deliver the best hospitality services to foreign and local guests. Thus, this study aimed to investigate the nature of existing major conflicts between engineers and technicians in the maintenance departments of Sri Lankan hotel facilities. A qualitative approach was adopted by using the case study research strategy (five nr of cases) and empirical data was collected via two expert interviews in each case, and document review within selected cases. Manual content analysis was used to analyze the data. The findings of this study revealed that 13 existence major conflicts between engineers and technicians in maintenance departments of Sri Lankan hotel facilities were based on seven conflict categories with comparing the literature findings.
\end{abstract}

Keywords: Conflict categories, Case studies, Content analysis, Maintenance department

\section{Introduction}

The hotel industry is one of the most important fast-growing sectors in the world economy (Cheng, 2018). The hotel industry provides significant contributions to the Sri Lankan economy as the third foreign exchange earning source (Sri Lanka Tourism Development Authority, 2017). The sources further state that the success of the hotel sector is depended on its occupancy level. Therefore, as a major economic sector in the Sri Lankan economy, hotel facilities must be well maintained to get attraction from both foreigners and local guests (Ambepitiya \& Dharmasiri, 2017). As a result of that, the maintenance department in every hotel has a significant role to achieve the success of the hotel industry (Ejikeme, et al., 2016).

Quality of the maintenance services in the hotel industry depends on the quality of the services of the employees because employees are considered as the backbone of every organisation and department (Ratnayake, et al., 2013). According to Lai (2012), teamwork always affects to enhance the quality services of employees in the maintenance department of hotel facilities. Furthermore, engineers and technicians are major professions that represent the maintenance team in the hotel industry (Ghazi, 2016). However, when working as a team, arising of conflicts is obvious between engineers and technicians because everybody may not defend and accept similar feelings, beliefs, preferences, thoughts, and attitudes, etc. (Yusuf \& Anuar, 2014). Thus, a conflict can be defined as "disagreement in opinions between people or group, due to differences in attitudes, beliefs, values or needs" (Thomas, 1992).

Conflicts between the engineers and technicians can create numerous destructive impacts as well as some constructive impacts on the performance of the maintenance department and the performance of the whole hotel industry. Destructive impacts lead to; Create industrial conflicts and disputes, Creating employee' job dissatisfaction, Delaying of maintenance works (it might be caused even to create unhappy customers), Consume additional costs and time, Creating requirements for legal advice, and increased turnover of maintenance staff, etc. (Chigozie, 2017; Hon \& Chan, 2013). Whilst constructive impacts can also be there since different perspectives can add novel approaches and innovation to workplace practices. These destructive impacts can be eliminated and understanding the nature of major conflicts between engineers and technicians in the maintenance department of the hotel industry can be the essential first step (Dann \& Hornsey, 1986). Therefore, this study is focused 
to investigate the nature of major conflicts between engineers and technicians in the maintenance departments of Sri Lankan hotel facilities.

\section{Literature Review}

\subsection{SIGNIFICANCE OF UNDERSTANDING THE NATURE OF MAJOR CONFLICTS BETWEEN ENGINEERS AND TECHNICIANS}

The nature of the jobs of maintenance employees in the Sri Lankan hotel sector is complex when compared to other countries (Ambepitiya \& Dharmasiri, 2017). As a result of that, several conflicts arose between the staff members in the maintenance departments during the working period (Yusuf \& Anuar, 2014). Nowadays, most of the conflicts are arisen between the engineers and technicians, because engineers are considered as managerial staff and technicians are considered as nonmanagerial staff in the Sri Lankan hotel industry (Ambepitiya \& Dharmasiri, 2017). The two parties gain different benefits from the organization as of their job level (Hon \& Chan, 2013). However, the success of maintenance services is highly dependent on both of the parties' performances (Lai, 2012). Moreover, there is an experience and knowledge gap between the engineers and technician's integration in the Sri Lankan hotel industry. As a result of that, arising of conflicts between the engineers and technicians can be considered as a common issue in the Sri Lankan hotel industry. As mentioned in the introduction, it can destructively affect the development of the Sri Lankan hotel industry.

However, in the first place, there is a lack of attention paid towards understanding the nature of those conflicts between the engineers and technicians in the Sri Lankan hotel industry, because of management of the Sri Lankan hotel sector has not properly weighed the significance of conflict management processes. It can be happened due to insufficient research on conflicts between the engineers and technicians in the Sri Lankan hotel industry.

\subsection{ENGINEER'S JOB ROLE IN THE MAINTENANCE DEPARTMENT OF HOTEL FACILITY: AN OVERVIEW}

According to Mishra and Pathak (2012), maintenance engineering can be defined as disciplines and vocation of relating to engineering approaches for the optimization of systems, equipment, maintenance costs, and procedures to ensure better availability, maintainability, and reliability of equipment and systems of the facility. The persons, who do the maintenance engineering practices can be called as maintenance engineers (Mishra \& Pathak, 2012). Maintenance engineers are managerial employees in organizations (Niebel, 1994). Furthermore, maintenance engineers are key persons, who have responsibilities in the maintenance department and all the employees of the maintenance department should be reported to the maintenance engineers (Muchiri, et al., 2011). Every maintenance engineer has the responsibility to carry out maintenance works of the hotel facility as planned to achieve maintenance standards (Lai, 2012). The number of maintenance engineers in the maintenance department of the hotel facility depends on the different factors such as the scope of maintenance works, nature of the hotel, size of the hotel, numbers of building services, organization structure and financial ability, etc. (Ghazi, 2016). For example, some hotels are recruited separate maintenance engineers for separate building services such as; electrical engineers, building work engineers, etc., and all engineers perform under the supervision of chief maintenance engineers (Lai \& Yik, 2012). Nevertheless, some hotels have recruited a single maintenance engineer to coordinate all the maintenance works of the hotel facility (Chan, et al., 2001). 


\subsection{TECHNICIAN'S JOB ROLE IN THE MAINTENANCE DEPARTMENT OF HOTEL FACILITY: AN} OVERVIEW

Technicians can be defined as persons, who have responsibilities for performing extremely differentiated tasks to install, maintain, troubleshoot, and repair the facility, systems, and equipment according to maintenance and safety standards to achieve better availability, maintainability, and reliability of equipment and systems of the facility (Stevenson, 1970). Most of the hotels are recruited separate technical staff to maintain the separate building service (Lai, 2012). Because, a technician is a person, who has specialized knowledge and experience in relevant building service (Stevenson, 1970). Accordingly, there are several technicians involved to carry out maintenance works related to building services in hotel facilities under different job titles such as; HVAC technicians, electricians, plumbers, building work technicians and general technicians, etc. (Chan, et al., 2001). According to Borsenik (1977), the number of technicians in the maintenance department is depended on several factors such as; the scope of maintenance works, nature of the hotel, size of the hotel, numbers of building services, organization structure, and financial ability, etc.

In most of the hotel facilities, technicians are considered as non-executive or non-managerial employees in the organization based on the organizational structure (Niebel, 1994). Therefore, technicians always reported to supervisors and engineers (Baum, 2002). However, technicians are the persons who perform the actual tasks and they have a better practical understanding of the maintenance of systems in the hotel facility than other staff members of the maintenance department (Trevelyan, 2007). Technicians provide 24 hours services to maintain different services in the hotel facility and they work on a shift basis (Yik \& Lai, 2005). As a result of that, technicians have become a key role in the hotel facility, and the hotel cannot be maintained without the support or employment of the technicians (Stevenson, 1970).

Reviewing both the roles; engineer and technician, in the maintenance department of the hotel, simply engineer can be considered as the person, who has advanced theatrical knowledge of maintenance works in the facility (Mishra \& Pathak, 2012) whereas a technician can be considered as the person, who has advanced practical knowledge and experience about maintenance works of the particular facility (Trevelyan, 2007). Furthermore, it can be implied as the engineer is a person, who gives advice and opinions to carry out maintenance activities (Muchiri, et al., 2011) whereas the technician is a person, who performs hotel maintenance tasks and activities (Yik \& Lai, 2005). Therefore, both engineer's and technician's work are essential to enhance the quality of services within the maintenance team of a hotel facility.

\subsection{MAJOR CONFLICTS BETWEEN THE ENGINEERS AND TECHNICIANS IN THE MAINTENANCE DEPARTMENT OF HOTEL FACILITY}

Most of the organizations encourage teamwork within their organizations, especially in the hotel industry. A maintenance department of a hotel facility should work as a team (Monica $\mathrm{Hu}$, et al., 2009). When working as a team, internal conflicts between the team members cannot be avoided. Conflict is an outcome of human behaviors' and it is becoming an integral part of employee life (Yirik, et al., 2015).

'Conflicts' have been investigated over the past ten decades by many researchers and great minds. In there, most of the researchers have attempted to define the 'conflict' in their ways. Simply, conflicts can be defined as the situation in which one person or party proposes that its benefits are being disparate or opposed by another person or party (Jehn \& Bendersky, 2003). Therefore, a conflict is a "disagreement in opinions between people or group, due to differences in attitudes, beliefs, values or 
needs" (Thomas, 1992, p. 265). A dynamic situation that happens between independent persons or parties as they perceived adverse emotional responses as a result of disagreements and arguments with the achievement of their goals also can be called as a conflict (Omisore \& Abiodun, 2014). According to Jehn and Bendersky (2003), conflict refers to the differential or discrepant views between the parties who are involved to work. Conflicts are directed to human minds to create negative emotions and feelings. According to that, the main seven types of conflicts between engineers and technicians in the maintenance department of the hotel facility can be identified (Yusuf \& Anuar, 2014) as Table 1;

Table 1: Types of conflicts

\begin{tabular}{|c|c|c|}
\hline Type of Conflict & Description & References \\
\hline $\begin{array}{l}\text { Conflicts of } \\
\text { relationships }\end{array}$ & $\begin{array}{l}\text { Disagreement about interpersonal incompatibilities among } \\
\text { engineers and technicians }\end{array}$ & $\begin{array}{l}\text { (Yusuf \& Anuar, } \\
\text { 2014) }\end{array}$ \\
\hline $\begin{array}{l}\text { Conflicts of cultural } \\
\text { differences }\end{array}$ & $\begin{array}{l}\text { Disagreement about cultural believes between engineer and } \\
\text { technician }\end{array}$ & (Isa, 2015) \\
\hline $\begin{array}{l}\text { Conflicts of } \\
\text { harassment, Bullying, } \\
\text { and Discrimination }\end{array}$ & $\begin{array}{l}\text { This type of conflict may affect the physical and mental health of } \\
\text { employees }\end{array}$ & (Isa, 2015) \\
\hline $\begin{array}{l}\text { Conflicts of } \\
\text { performance } \\
\text { differences }\end{array}$ & $\begin{array}{l}\text { Disagreement about the quality of the employee's services. When } \\
\text { the technician did not comply with the quality level that is } \\
\text { expected by an engineer, conflict may arise between the engineer } \\
\text { and the technician }\end{array}$ & $\begin{array}{l}\text { (Yusuf \& Anuar, } \\
\text { 2014) }\end{array}$ \\
\hline $\begin{array}{l}\text { Conflicts of unclear } \\
\text { responsibilities }\end{array}$ & $\begin{array}{l}\text { When it is unclear who is responsible for what works in an } \\
\text { organisation, conflicts may occur }\end{array}$ & (Tjosvold, 2008) \\
\hline $\begin{array}{l}\text { Conflicts of the } \\
\text { process }\end{array}$ & $\begin{array}{l}\text { A process conflict can be defined as a disagreement over the } \\
\text { methods and procedures that can be used to accomplish a task. } \\
\text { To be more specific, a process conflict will be associated with the } \\
\text { allocation of resources; and duties, and responsibilities to } \\
\text { different people to accomplish a task }\end{array}$ & (Tjosvold, 2008) \\
\hline Conflicts of tasks & $\begin{array}{l}\text { A task conflict can be defined as a disagreement among group } \\
\text { members or individuals about their decisions, viewpoints, ideas, } \\
\text { and opinions. As examples of task conflict are disagreements } \\
\text { about the content of tasks and occupant goals such as the } \\
\text { distribution of resources, interpretation of facts, and operation } \\
\text { procedures. }\end{array}$ & (Poole, et al., 1991) \\
\hline
\end{tabular}

Most of the past researchers have considered the above seven types of conflicts mentioned, as the main categories of conflicts between the engineers and technicians in the maintenance department of the hotel industry throughout the world.

\section{Research Method}

A systematic framework that describes the way to accomplish the research aim and objectives can be called as a research methodology (Fellows \& Liu, 2008). The appropriate research approach is depended on the research question. The research problem can be elaborated on different types of questions namely what, why, who, where, and how (Yin, 2009). Commonly, five different types of research approaches can be adopted in research: experiment, survey, archival analysis, case study, and history (Rowley, 2002). To identify the major conflicts between the engineers and technicians in the 
maintenance department, the behavioral nature of the engineers and technicians had to be studied. Therefore, a case study based qualitative research approach was selected for the study. According to Yin (2009), the number of cases in a case study could vary from one to eight depending on the nature of the study. For this study, five main five star hotels in Colombo, Sri Lanka, which had approximately similar hospitality services and facilities to local and foreign guests, were selected. The data required were collected using semi-structured interviews. The interviews were selected as the data collection method to abstract data from real-life scenarios from the concerned main perspectives of the research. The key professionals who involve managing conflicts between the engineers and technicians in selected cases were interviewed and the data collected were analyzed through cross-case analysis via content analysis. Table 2 below presents the details of the five cases and the details of the professionals who were interviewed.

Table 2: Details of the participants for interviews

\begin{tabular}{|c|c|c|c|}
\hline $\begin{array}{c}\text { Interviewee } \\
\text { code (IC) }\end{array}$ & Designation & Location of work & $\begin{array}{c}\text { Year of } \\
\text { experience }\end{array}$ \\
\hline \multicolumn{4}{|c|}{ Case A } \\
\hline IC-A-O1 & Human Resource Manager & HR Department & 15 years \\
\hline IC-A-O2 & Engineer & Engineering Department & 8 years \\
\hline \multicolumn{4}{|c|}{ Case B } \\
\hline IC-B-O1 & Human Resource Manager & HR Department & 7 years \\
\hline IC-B-O2 & Engineer & Engineering Department & 10 years \\
\hline \multicolumn{4}{|c|}{ Case C } \\
\hline IC-C-O1 & Human Resource Manager & HR Department & 7 years \\
\hline IC-C-O2 & Engineer & Engineering Department & 6 years \\
\hline \multicolumn{4}{|c|}{ Case D } \\
\hline IC-D-O1 & Human Resource Manager & HR Department & 5 years \\
\hline IC-D-O2 & Engineer & Engineering Department & 10 years \\
\hline \multicolumn{4}{|c|}{ Case E } \\
\hline IC-E-O1 & Human Resource Manager & HR Department & 5 years \\
\hline IC-E-O2 & Engineer & Engineering Department & 9 years \\
\hline
\end{tabular}

\section{Research Findings and Discussion}

The research findings are discussed under two categories: applicability of conflict categories to the maintenance department in Sri Lankan hotel facilities, and existing major conflicts between engineers and technicians based on applicable conflict categories.

\subsection{APPLICABILITY OF CONFLICT CATEGORIES TO THE MAINTENANCE DEPARTMENT IN THE SRI LANKAN HOTEL INDUSTRY}

As a result of the literature findings of this study, seven main categories of conflicts between the engineers and technicians in the maintenance department were found out. Through the semistructured interviews conducted with the person from the human resource management department who engages in selected cases for conflict management, the applicability of seven categories of 
conflicts in the Sri Lankan hotel industry was determined. The collected data from respondents of selected cases on the applicability of categories of conflicts are shown in Table 3.

Table 3: Applicability of conflict categories to the maintenance department of Sri Lankan hotel facilities

\begin{tabular}{|c|c|c|c|c|c|c|}
\hline \multirow{3}{*}{ Conflict } & \multicolumn{5}{|c|}{$\begin{array}{c}\text { Applicability of Conflict Categories in } \\
\text { Selected Cases }\end{array}$} & \multirow[t]{3}{*}{ Comments } \\
\hline & $\begin{array}{l}\text { IC-A- } \\
01\end{array}$ & $\begin{array}{l}\text { IC-B- } \\
\text { o1 }\end{array}$ & $\begin{array}{l}\text { IC-C- } \\
\text { o1 }\end{array}$ & $\begin{array}{l}\text { IC-D- } \\
01\end{array}$ & $\begin{array}{l}\text { IC-E- } \\
01\end{array}$ & \\
\hline & & & & & & \\
\hline $\begin{array}{l}\text { Conflicts of } \\
\text { relationships }\end{array}$ & $\checkmark$ & $\checkmark$ & $\checkmark$ & $\checkmark$ & $\checkmark$ & \multirow{2}{*}{$\begin{array}{l}\text { All participant believed } \\
\text { disagreement arise based on their } \\
\text { working relations and conflicts } \\
\text { also happened due to cultural } \\
\text { differences }\end{array}$} \\
\hline $\begin{array}{l}\text { Conflicts of } \\
\text { cultural } \\
\text { differences }\end{array}$ & $\checkmark$ & $\checkmark$ & $\checkmark$ & $\bar{\checkmark}$ & $\bar{\checkmark}$ & \\
\hline $\begin{array}{l}\text { Conflicts of } \\
\text { harassment, } \\
\text { bullying, and } \\
\text { discrimination }\end{array}$ & & $\checkmark$ & & $\checkmark$ & $\checkmark$ & $\begin{array}{l}\text { Participants in Case A \& C } \\
\text { believed there are no conflicts } \\
\text { based on this category, however } \\
\text { other argued that statement when } \\
\text { mentioning its applicability }\end{array}$ \\
\hline $\begin{array}{l}\text { Conflicts of } \\
\text { performance } \\
\text { differences }\end{array}$ & $\checkmark$ & $\checkmark$ & $\checkmark$ & $\bar{\checkmark}$ & $\bar{\checkmark}$ & $\begin{array}{l}\text { As a key category, the applicability } \\
\text { of conflict of performance } \\
\text { differences was accepted by all } \\
\text { participants }\end{array}$ \\
\hline $\begin{array}{l}\text { Conflicts of } \\
\text { unclear } \\
\text { responsibilities }\end{array}$ & & $\checkmark$ & $\checkmark$ & $\checkmark$ & $\checkmark$ & $\begin{array}{l}\text { Participant in Case A did not } \\
\text { believe there is unclear } \\
\text { responsibility }\end{array}$ \\
\hline $\begin{array}{l}\text { Conflicts of } \\
\text { process }\end{array}$ & $\sqrt{ }$ & $\checkmark$ & $\checkmark$ & $\checkmark$ & $\checkmark$ & $\begin{array}{l}\text { Most of the interviewee's } \\
\text { suggested merging these conflict }\end{array}$ \\
\hline Conflicts of tasks & & & $\checkmark$ & & & $\begin{array}{l}\text { categories as one category due to } \\
\text { their similar characteristics }\end{array}$ \\
\hline $\begin{array}{l}\text { Other } \\
\text { Conflicts of } \\
\text { benefits gain }\end{array}$ & $\checkmark$ & $\checkmark$ & $\checkmark$ & & $\checkmark$ & $\begin{array}{l}\text { Apart from Case D, this was } \\
\text { mentioned as a conflict in all other } \\
\text { cases }\end{array}$ \\
\hline $\begin{array}{l}\text { Conflicts of } \\
\text { common } \\
\text { resource } \\
\text { allocation \& } \\
\text { sharing }\end{array}$ & $\checkmark$ & & $\checkmark$ & $\checkmark$ & & $\begin{array}{l}\text { The majority of participants } \\
\text { believed common resources } \\
\text { allocation and their sharing are } \\
\text { affected to arise conflict }\end{array}$ \\
\hline
\end{tabular}

Besides seven main conflict categories that were found out from the past studies such as (Isa, 2015); (Jehn \& Bendersky, 2003); (Tjosvold, 2008); (Yirik, et al., 2015); (Yusuf \& Anuar, 2014), two main categories were added by the respondents in selected cases i.e. conflicts of benefits gain and conflicts of common resource allocation and sharing. Furthermore, among the respondents, IC-A-01, IC-B-O1, IC-D-01, and IC-E-01 mentioned that conflicts of process and conflicts of tasks have similar characteristics based on sources and impacts of them. Therefore, both conflicts of process and conflicts of tasks can be considered as applicable to one category of conflict between engineers and technicians in maintenance departments in the Sri Lankan hotel industry. Yet, IC-C-o1 disagreed with that, mentioned both conflicts of process and conflicts of tasks have occurred between engineers and 
technicians in the Sri Lankan hotel industry separately. However, based on the findings from the majority of participants, as a summary of the applicability of conflict categories to the maintenance department in the Sri Lankan hotel industry, conflicts are arising between engineers and technicians in the maintenance department of Sri Lankan hotel industry based on eight main conflict categories i.e. i) Conflicts of relationships, ii) Conflicts of cultural differences, iii) Conflicts of performance differences, iv) Conflicts of process or conflicts of tasks, v) Conflicts of unclear responsibility, vi) Conflicts of benefits gain, vii) Conflicts of harassment, bullying, and discrimination, and viii) conflicts of common resource allocation and sharing.

\subsection{EXISTING MAJOR CONFLICTS BETWEEN THE ENGINEERS AND TECHNICIANS IN MAINTENANCE DEPARTMENTS OF THE SRI LANKAN HOTEL INDUSTRY}

Based on eight main conflict categories, the findings of this study revealed major conflicts between engineers and technicians in the maintenance department of the Sri Lankan hotel industry as given in Table 4.

Table 4: Existing major conflicts between engineers and technicians

\begin{tabular}{|c|c|c|c|c|c|c|c|c|c|c|c|}
\hline \multirow{2}{*}{\begin{tabular}{|l|} 
TYPE \\
OF \\
CONFLI \\
CT
\end{tabular}} & \multirow[t]{2}{*}{ MAJOR CONFLICTS } & \multicolumn{2}{|c|}{ CASE A } & \multicolumn{2}{|c|}{ CASE B } & \multicolumn{2}{|c|}{ CASE C } & \multicolumn{2}{|c|}{ CASE D } & \multicolumn{2}{|c|}{ CASE E } \\
\hline & & $\begin{array}{l}\text { IC- } \\
\text { A- } \\
\text { o1 }\end{array}$ & $\begin{array}{l}\text { IC- } \\
\text { A- } \\
02\end{array}$ & $\begin{array}{l}\text { IC- } \\
\text { B- } \\
\text { o1 }\end{array}$ & $\begin{array}{l}\text { IC- } \\
\text { B- } \\
02\end{array}$ & $\begin{array}{l}\text { IC- } \\
\text { C- } \\
\text { o1 }\end{array}$ & $\begin{array}{l}\text { IC- } \\
\text { C- } \\
\text { o2 }\end{array}$ & $\begin{array}{l}\text { IC- } \\
\text { D- } \\
\text { o1 }\end{array}$ & $\begin{array}{l}\text { IC- } \\
\text { D- } \\
\text { o2 }\end{array}$ & $\begin{array}{l}\text { IC- } \\
\text { E- } \\
\text { o1 }\end{array}$ & $\begin{array}{l}\text { IC- } \\
\text { E- } \\
\text { o2 }\end{array}$ \\
\hline \multirow{3}{*}{ 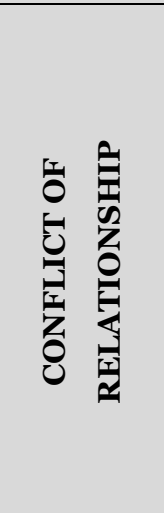 } & $\begin{array}{l}\text { Conflicts between non- } \\
\text { experience engineers \& } \\
\text { experienced technicians }\end{array}$ & $\checkmark$ & $\checkmark$ & $\checkmark$ & $\checkmark$ & $\checkmark$ & $\checkmark$ & $\checkmark$ & $\checkmark$ & $\sqrt{ }$ & $\checkmark$ \\
\hline & $\begin{array}{l}\text { Conflicts between new } \\
\text { employee engineers \& } \\
\text { old technicians in hotel }\end{array}$ & & & $\checkmark$ & $\checkmark$ & & $\checkmark$ & & & $\checkmark$ & $\checkmark$ \\
\hline & $\begin{array}{l}\text { Conflicts between female } \\
\text { engineers \& male } \\
\text { technicians }\end{array}$ & $\sqrt{ }$ & $\checkmark$ & & & $\checkmark$ & $\checkmark$ & $\sqrt{ }$ & $\checkmark$ & & \\
\hline \multirow{2}{*}{ 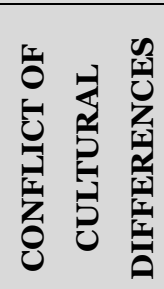 } & $\begin{array}{l}\text { Conflicts on cultural } \\
\text { beliefs }\end{array}$ & $\checkmark$ & $\checkmark$ & $\checkmark$ & $\checkmark$ & $\checkmark$ & $\checkmark$ & $\checkmark$ & $\checkmark$ & $\checkmark$ & $\checkmark$ \\
\hline & $\begin{array}{l}\text { Conflicts on cultural } \\
\text { thoughts }\end{array}$ & $\checkmark$ & $\checkmark$ & $\checkmark$ & $\checkmark$ & $\checkmark$ & $\checkmark$ & $\checkmark$ & $\checkmark$ & $\checkmark$ & $\checkmark$ \\
\hline \multirow{3}{*}{ 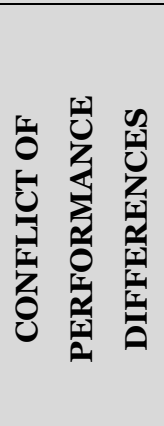 } & $\begin{array}{l}\text { Conflicts between the } \\
\text { engineer's performance } \\
\text { target setting and the } \\
\text { technician's performance } \\
\text { target settings }\end{array}$ & $\checkmark$ & $\checkmark$ & $\checkmark$ & $\checkmark$ & $\checkmark$ & $\checkmark$ & $\checkmark$ & $\checkmark$ & $\checkmark$ & $\checkmark$ \\
\hline & $\begin{array}{l}\text { Conflicts on working } \\
\text { quality of technicians }\end{array}$ & $\checkmark$ & $\checkmark$ & $\checkmark$ & $\checkmark$ & $\checkmark$ & $\checkmark$ & $\checkmark$ & $\checkmark$ & $\checkmark$ & $\checkmark$ \\
\hline & Conflicts on engineer's & $\checkmark$ & $\checkmark$ & & & $\checkmark$ & $\checkmark$ & $\checkmark$ & $\checkmark$ & $\checkmark$ & $\checkmark$ \\
\hline
\end{tabular}




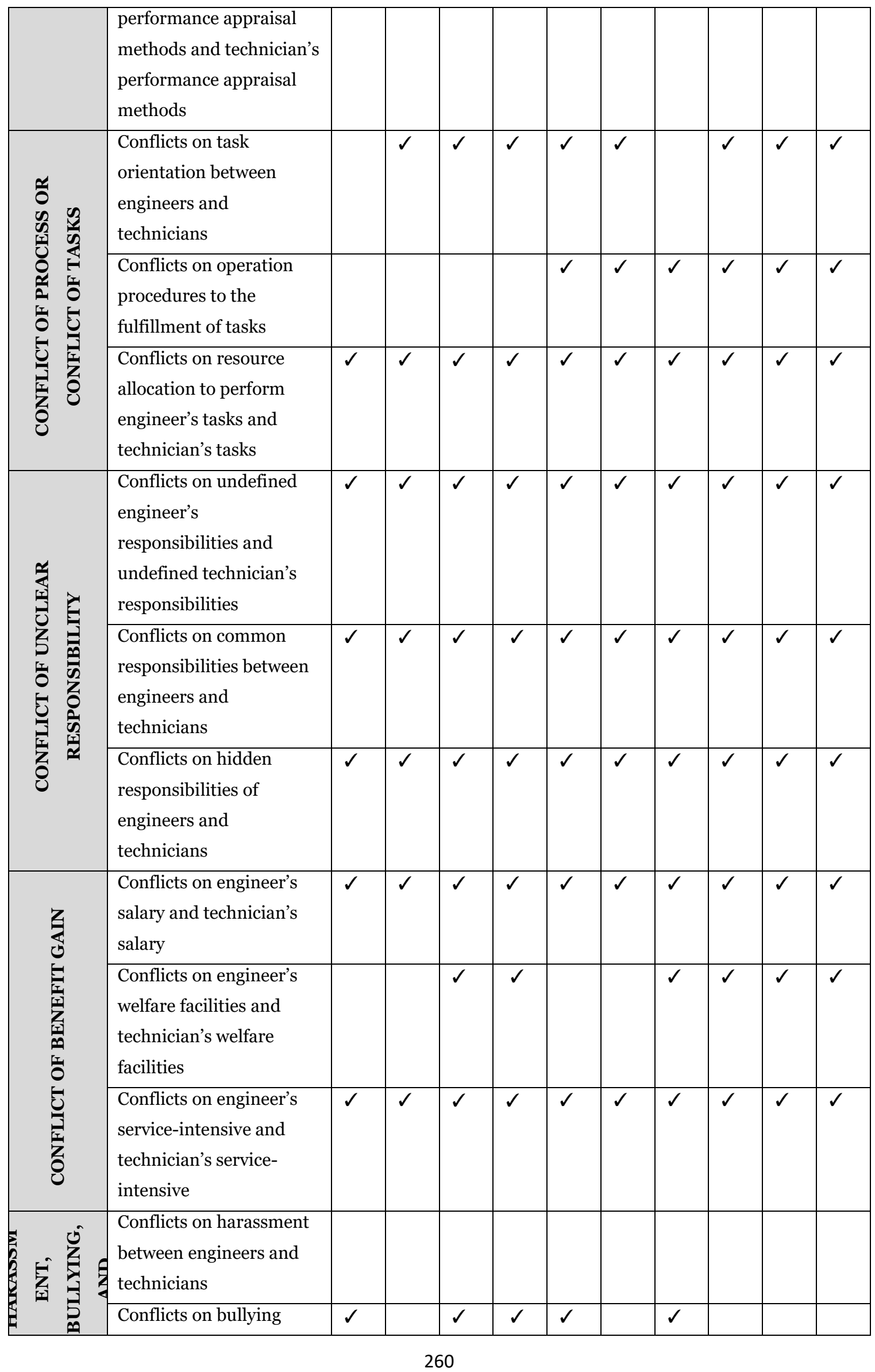




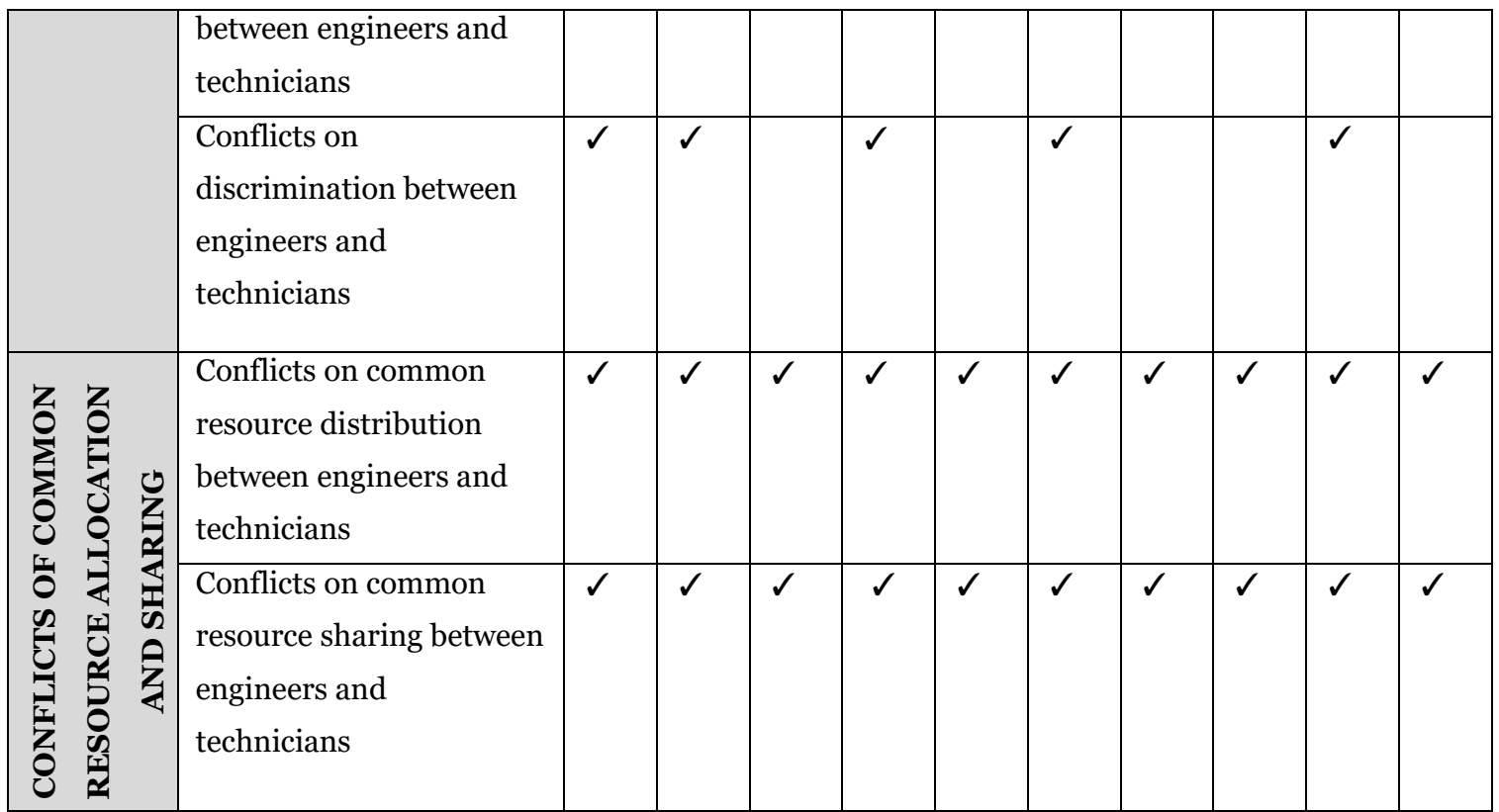

According to Table 4, three major conflicts were revealed by the participants for the interviews. However, among these conflicts, findings revealed that conflicts between non-experience engineers and experienced technicians are major conflicts among all selected cases. All the participants believed that they were adversely affected by the performance of the maintenance department. Moreover, both conflicts that were determined based on cultural differences as Table 4 were found out from all selected cases. Case study findings also revealed that conflicts between engineer's performance target setting and technician's performance target settings and conflicts on the working quality of technicians are major conflicts based on the conflict of performance differences category in all selected cases. Conflicts on resource allocation to perform engineer's tasks and technician's tasks are the main conflict between engineers and technicians under the conflict of process or tasks category. Because technicians always complain they have not adequate resources to perform their tasks yet engineers have over resources with comparing the engineer's tasks. Also, technicians believe there is fluctuation when distributing the resources between engineers and technicians in the maintenance department of the Sri Lankan hotel industry. All the conflicts that were found out based on conflict of unclear responsibility can be considered as major conflicts because all participants in selected cases believed these conflicts are arising their facilities. Conflicts on engineer's salary and technician's salary and conflicts on service-intensive and technician's service intensive. Because of technicians were not satisfied with their salary and service intensives because they believed engineers have more salary and service-intensive than their performance and responsibilities.

Respondents in selected cases mentioned conflicts have not been arisen due to harassment between engineers and technicians in the maintenance department in the Sri Lankan hotel industry. However, literature findings were found out conflicts create due to harassment whereas through the observation in a selected case, verbal harassments were determined. Nevertheless, all the respondents in selected cases have not mentioned any harassment in their hotel facilities. However, IC-A-01, IC-B-01, IC-B02, IC-C-01, and IC-D-O1 mentioned conflicts on bullying between engineers and technicians can be determined under conflicts of harassment, bullying, and discrimination whereas IC-A-01, IC-A-02, ICB-O2, IC-D-02, and IC-E-O1 mentioned conflicts on discrimination between engineers and technicians also can be determined under conflicts of harassment, bullying, and discrimination. Conflicts on common resource distribution between engineers and technicians and conflicts on common resource sharing between engineers and technicians are the main conflicts in selected five cases based on respondents. Because all the respondents mentioned both of these conflicts are arising between engineers and technicians in the maintenance department of the Sri Lankan hotel industry. Always 
technicians complained engineers have more benefits when distribute and share the common resources. As a result of that, conflicts are arising between them.

According to the above findings of case studies, 22 conflicts between engineers and technicians in the maintenance department of the Sri Lankan hotel industry were revealed whereas 13 conflicts were determined as major conflicts between engineers and technicians in the maintenance department of Sri Lankan hotel industry based on their applicability to all selected cases and degree of occurrences in all selected cases (refer Table 3). In addition to that, eight conflicts were revealed by the participants as conflicts between engineers and technicians in the maintenance department of the Sri Lankan hotel industry. Nevertheless, conflict on harassment was not revealed as conflicts between engineers and technicians in the maintenance department of the Sri Lankan hotel industry due to its absence in all selected cases. These findings are useful to manage conflicts between engineers and technicians in the maintenance department of the Sri Lankan hotel industry to achieve better quality maintenance services from the departments.

\subsection{Conclusion}

This study focused on investigating major conflicts between engineers and technicians in the maintenance department of the Sri Lankan hotel industry. There are seven main conflicts between the engineers and technicians in the maintenance department were found out through the literature review such as conflicts of relationships, conflicts of cultural differences, conflicts of harassment, bullying, and discrimination, conflicts of performance differences, conflicts of unclear responsibilities, conflicts of process and conflicts of tasks. These conflict categories were validated by the respondents of semi-structured interviews. As per the findings of case studies, seven categories changed into eight categories. Because of conflicts of benefits gain and conflicts of common resource allocation and sharing were added by the participants in case studies apart from the conflicts that were identified in the literature review whereas case study participants suggested merging the process conflict and task conflict due to their similar characteristics. Conflicts of process and conflicts of tasks were determined as separately in the literature review. Yet, it was merged as conflicts of process or tasks by the respondents. Also, conflicts of benefits gain and conflicts of common resource allocation and sharing are added by the respondents of semi-structured interviews in five selected cases. Furthermore, 22 conflicts were found out from case studies based on the above eight main categories. At the end of data analysis, 13 conflicts were determined as major conflicts between engineers and technicians in the maintenance department of the Sri Lankan hotel industry. These findings useful to implement proper conflict management systems within the Sri Lankan hotel industry whereas findings encourage to carry out the future researches based on different categories of conflicts between engineers and technicians in the maintenance department of the Sri Lankan hotel industry.

\section{6.o References}

Ambepitiya, K. R. \& Dharmasiri, U. R., 2017. The study of professional training to improve customer satisfaction in small and medium scale hotels in Sri Lanka. Colombo Business Journal: International Journal of Theory and Practice, 8(1), pp. 82 105 .

Baum, T., 2002. Skills and training for the hospitality sector: a review of issues. Journal of Vocational Education \& Training, 54(3), pp. 343-364.

Borsenik, F., 1977. The Role of the Engineering and Maintenance Course in Hospitality Education. Journal of Hospitality \& Tourism Research, 2(1), pp. 39-46.

Chan, K., Lee, R. \& Burnett, J., 2001. Maintenance performance: A case study of hospitality engineering systems. Facilities, 19(13/14), pp. 494-504.

Cheng, B. L., 2018. Service recovery, customer satisfaction, and customer loyalty: evidence from Malaysia's hotel industry. International Journal of Quality and Service Sciences.

Dann, D. \& Hornsey, T., 1986. Towards a theory of interdepartmental conflict in hotels. International Journal of Hospitality Management, 5(1), pp. 23-28. 
Ejikeme, J. N., Enemuo, O. B. \& Edward, C., 2016. The role of customer satisfaction and maintenance culture in the sustainability of hospitality industries in Umuahia North and South Local Government Areas of Abia State. Journal of Hospitality Management and Tourism, 7(1), pp. 1-10.

Evans, H., 2003. Plumbers and architects - A supervisory perspective on International Financial Architecture. SSRN Electronic Journal, pp. 1-32.

Ambepitiya, K. R. \& Dharmasiri, U. R., 2017. The study of professional training to improve customer satisfaction in small and medium scale hotels in Sri Lanka. Colombo Business Journal: International Journal of Theory and Practice, 8(1), pp. 82 105 .

Baum, T., 2002. Skills and training for the hospitality sector: a review of issues. Journal of Vocational Education \& Training, 54(3), pp. 343-364.

Borsenik, F., 1977. The Role of the Engineering and Maintenance Course in Hospitality Education. Journal of Hospitality \& Tourism Research, 2(1), pp. 39-46.

Chan, K., Lee, R. \& Burnett, J., 2001. Maintenance performance: A case study of hospitality engineering systems. Facilities, 19(13/14), pp. 494-504.

Cheng, B. L., 2018. Service recovery, customer satisfaction, and customer loyalty: evidence from Malaysia's hotel industry. International Journal of Quality and Service Sciences.

Dann, D. \& Hornsey, T., 1986. Towards a theory of interdepartmental conflict in hotels. International Journal of Hospitality Management, 5(1), pp. 23-28.

Ejikeme, J. N., Enemuo, O. B. \& Edward, C., 2016. The role of customer satisfaction and maintenance culture in the sustainability of hospitality industries in Umuahia North and South Local Government Areas of Abia State. Journal of Hospitality Management and Tourism, 7(1), pp. 1-10.

Evans, H., 2003. Plumbers and architects - A supervisory perspective on International Financial Architecture. SSRN Electronic Journal, pp. 1-32.

Ghazi, 2016. Hotel maintenance management practices. Journal of Hotel \& Business Management, 5(1), pp. 1 - 8.

Harmon, D., 2010. A Career as an Electrician. New York: The Rosen Publishing Group.

Heinemeier, K. et al., 2012. Uncertainties in Achieving Energy Savings from. Texas, San Antonio, p. 8.

Hon, A. H. Y. \& Chan, W. W., 2013. The effects of group conflict and work stress on employee performance. Cornell Hospitality Quarterly, 54(2), pp. 174-184.

Isa, A. A., 2015. Conflicts in Organizations: Causes and Consequences. Journal of Educational Policy and Entrepreneurial Research (JEPER), 2(11), pp. 54-59.

Jehn, K. \& Bendersky, C., 2003. Intragroup conflict in organizations: A contingency perspective on the conflict-outcome relationship. Research in Organizational Behavior, 25(1), pp. 187-242.

Lai, J. H., 2012. An analysis of maintenance demand, manpower, and performance of hotel engineering facilities. Journal of Hospitality \& Tourism Research, 37(3), pp. 426-444.

Mishra, R. \& Pathak, K., 2012. Maintenance Engineering and Management. Second ed. New Delhi: PHI Learning Pvt.

Monica Hu, M., Horng, J. \& Christine Sen, Y., 2009. Hospitality teams: Knowledge sharing and service innovation performance. Tourism Management, 30(1), pp. 41-50.

Muchiri, P., Pintelon, L., Gelders, L. \& Martin, H., 2011. Development of maintenance function performance measurement framework and indicators. International Journal of Production Economics, 131(1), pp. 295-302.

Niebel, B., 1994. Engineering Maintenance Management. Second ed. Florida: CRC Press.

Omisore, B. O. \& Abiodun, A. . R., 2014. Organizational Conflicts: Causes, Effects, and Remedies. International Journal of Academic Research in Economics and Management Sciences, 3(6), pp. 118-137.

Poole, M. S., Holmes, M. \& Desanctis, G., 1991. Conflict Management in a Computer-Supported Meeting Environment. Management Science, 37(8), pp. 926-953.

Ratnayake, R. M. T. H., Menike, E. D. T. M. N. D. \& Perera, T., 2013. Factors affecting the growth of SMEs in the tourism industry in Sri Lanka. Sri Lankan Journal of Management, 18(3), pp. 114 - 137.

Rojas, E., 2013. Identifying, Recruiting, and Retaining Quality Field Supervisors and Project Managers in the Electrical Construction Industry. Journal of Management in Engineering, 29(4), pp. 424-434.

Rowley, J., 2002. Using case studies in research. Management Research News, 25(1), pp. 16-27.

Siu, V., 1998. Managing by competencies-a study on the managerial competencies of hotel middle managers in Hong Kong. International Journal of Hospitality Management, 17(3), pp. 253-273.

Sri Lanka Tourism Development Authority, 2017. The annual statistical report, s.l.: Sri Lanka Tourism Development Authority.

Stevenson, R., 1970. Training the TECHNICIAN ENGINEER. Industrial and Commercial Training, 2(1), pp. 31-34.

Thomas, K. W., 1992. Conflict and negotiation in organizations: Historical and contemporary. Journal of Organizational Behavior, Volume 13, pp. 265-274. 
Tjosvold, D., 2008. The conflict-positive organization: It depends upon us. The conflict-positive organization: It depends upon us, 29(1), pp. 19-28.

Trevelyan, J., 2007. Technical Coordination in Engineering Practice. Journal of Engineering Education, 96(3), pp. 191-204. Yik, F. \& Lai, J., 2005. The trend of outsourcing for building services operation and maintenance in Hong Kong. Facilities, 23(1/2), pp. 63-72.

Yin, R. K., 2009. Case study research: Design and methods. Thousand Oaks: Sage Publications.

Yirik, S., Yõldõrõm, B. \& Çetinkaya, N., 2015. A study on conflict management and conflict resolution in hospitality organizations. International Journal of Arts \& Sciences, 8(8), pp. 77 - 88.

Yusuf, B. N. B. M. \& Anuar, S. N. B. S., 2014. The effects of conflict handlings in the teamwork of hotel industry located in the Northern region of Malaysia. Journal of Asian Scientific Research, 4(11), pp. 603 - 617. 